\title{
Blended learning Teaching Techniques in Higher Education in India
}

\author{
Ms. Anuradha Pandit \\ (Assistant Professor, St. Kabir Institute of Professional Studies, Ahmedabad, Gujarat)
}

\begin{abstract}
India is a unique country. Education in India has always been a challenge. With wide diversity in demography and great geographical spread, ensuring that there is even spread of education in all the corners of the country is an uphill task. Higher education in India has seen a lot of changes in the current decade. With the increase in intake ratios in higher education institutes, as envisioned by the $11^{\text {th }}$ Five Year Plan (2007-2012), and the rapidly rising demands of use of technology as part of the teaching pedagogy, blended learning seems to be the only solution to this problem.

This concept paper explores the history of the use of blended learning techniques in higher education in India and explores the current trends in use. It also explores the challenges in the use of this technique through a review of existing literature and tries to offer strategies for making the technique effective for the achievement of its target.
\end{abstract}

Key Words : Higher education, Blended learning in India, Challenges, Strategies

\section{Introduction :}

Higher education in India has faced a lot of challenges. Considering the wide geographical expanse of the country and the diversity of the population, spreading education among the mass is an uphill task. In addition to this, learners come from diverse backgrounds and their needs are also different. Therefore flexibility of learning is something which needs to be worked upon in order to ensure that learning targets are met. The answer to this flexibility is the use of blended learning techniques in higher education, which allows for flexibility in course content and innovative use of technology in order to cater to the needs of the diversity of learning needs.

What is Blended Learning? A simplistic definition of the team is, Blended Learning is a combination of e-learning techniques with other forms of learning like face to face instructions by the teacher (Azizan, 2010).Singh defines it as a combination of multiple delivery media designed to complement each other and promote learning and application 
learned behavior. (Singh, 2003)Graham definedit as a combination of face to face and computer-mediated instruction (Graham, 2006) (Osguthorpe \& Graham, 2003).

But the term blended learning encompasses much more than a mere blend. It talks about the creation of a wholistic learning environment for effective impartation of instruction to the learner. Margaret Driscoll defines it as combining any form of instructional technology (e.g., videotape, web-based training, film, etc.) with face-to-face instructor-led training (Driscoll, nd). Purnima Valiathan describes blended learning as a solution that combines different delivery methods, such as software, Web-based courses, and learning management systems along with various event-based activities like face to face interaction, e-learning, and selfpaced learning (Valiathan, 2002).Instructors have the freedom to design learning systems differing on the basis of speed and frequency of learning and the rigor imposed on the learner. The onus of learning is also shifted from the shoulder of the instructor to those of the learner- making it a learner-centric approach to education.

\section{Blended Learning in India :}

Learning systems in India have seen a variety of changes over the passage of time. Dr. Ritu Sharma (Sharma \& Mahajan, 2017) through her research traces the gradual evolution of education systems in India and relates it to the changing phases of history. The Vedic age saw learning taking place at gurukulswhich offered residential programs at the guru's ashram and learners were taught spiritual texts and knowledge for life. However, with the advancement of technology and changing learning environments, gurukuls have become a thing of the past. With the introduction of colonial culture in India through the British education system, the focus shifted to mass learning systems. Education in India from the elementary school to university levels was more focussed on encouraging rote learning, rather than comprehension, critical thinking, and problem-solving (Jha \& Parvati, 2014)

Modern Mediated learning approaches adopted by teachers nowadays have seen a resurgence of emphasis on individualized learning mechanisms. With techniques like flipped classrooms and activity-based self-paced learning and online instruction methods, recognition of the learning needs of individual learners have gained importance. One of the initiatives taken by Indian Education System was the introduction of Train 10000 Teachers initiative coming up with blended courses using asynchronous remote centre for delivery of content, and the National Programme on Technology Enhanced Learning(NPTEL)which provided video repositories of professors of premier institutes like IITs and IIMs. This led to development of a trend of technology-based learning systems being commonly used for classroom teaching. 


\section{Challenges faced by Indian Higher Education :}

The economic and democratic diversity of learners are the main challenges faced by Indian higher education. Some of the other challenges are the variety of learning needs, demand for flexibility of course content and increasing demand for the use of information and communication technology tools (ICT). Besides this, other challenges in Indian education includes infrastructural, socio-economic, linguistic, and physical barriers which exist in India restricting access to education (Bhattacharya \& Sharma, 2007)Dearth of quality teachers for imparting education is also a problem (Bansal, 2014).

Blended learning seems to be the most appropriate solution to such challenges. This pedagogy allows the delivery of high quality, up-to-date learning solutions keeping the restrictions of education budgets in mind (Thorne, 2003)

It is predicted to help increase enrolment rations for higher education and is also in keeping with our culture, ethos, and social environment (Bansal, 2014). The use of blended learning techniques in teaching allows students to interact with their peers and instructors both inside and outside the classroom. It allows active self-paced learning with the flexibility of access. This also calls for a reduction of classroom time, learning to lower burden of infrastructure requirements for learning. However, the challenge is not only to effectively introduce blended learning techniques in teaching pedagogy but to efficiently blend the techniques in order to reach the desired learning outcome.

Blended learning teaching pedagogy offers a number of advantages. With a substantial percentage of higher education learners nowadays being nontraditional- attempting to balance family, jobs and academics, flexibility has become the key factor of concern. With reduction in classroom time offered by blended learning courses, this has helped reduce dropout rations of courses at universities.

But blended learning teaching techniques are not without their limitations. The challenges of the technique are manifold. Instructors need to be equipped with the latest technical knowledge. Also, they need to ensure the right mix of techniques for maximum effectiveness. Planning of the use of blend needs to be done effectively for successful implementation. The techniques need to be aligned with learning objectives to ensure effectiveness of the blend.

\section{Conclusion :}

The Indian education system, in its traditional format, is transforming- though slowly. With the introduction of blended learning techniques in teaching pedagogy, the roles and responsibilities of teachers as well as learners have undergone a massive transformation. But this transformation is not yet over- in fact it is the evolution in process. The challenge lies in making the use of blended techniques effectively as well as efficiently in order to achieve the maximum learning outcome. Or else Indian education may be caught in the web of ineffective techniques of teaching and thereby produce ineffective graduates who may be rejected by the corporate world, according to Darwin's theory of survival of the fittest. 


\section{References :}

1. Azizan, F. Z. (2010). Blended Learning in HIgher Education Institution in Malaysia. Proceedings of Regional Conference on Knowledge Integration in ICT 2010, 454466.

2. Bansal, D. P. (2014). Blended Learning in Indian Higher Education: Challenges and Strategies. International Journal of Applied Research and Studies (iJARS) , 3 (2), 113.

3. Bhattacharya, I., \& Sharma, K. (2007). India in the Knowledge Economy- an Electronic Choice for Higher Education Institutions. (U. o. Surrey, Ed.) UK: Unpublished.

4. Driscoll, M. (nd). Blended Learning: Let's Get Beyond the Hype. Retrieved November 2019, from https://www-07.ibm.com/services/pdf/blended_learning.pdf

5. Graham, C. R. (2006). Blended Learning Systems: Definition, Current Trends, and Future Directions. . In C. a. Bonk, Handbook of Blended Learning: Global Perspectives, Local Designs 3-21. San Francisco: Pfeiffer Publishing.

6. Jha, P., \& Parvati, P. (2014). Assessing Progress on Universal Elementary Education in India. Economic and Political Weekly, 49 (16), 44-51.

7. Osguthorpe, R. T., \& Graham, C. (2003). Blended Learning Environments: Definitions and Directions. Quarterly Review of Distance Education , 4 (3), 227.

8. Sharma, R., \& Mahajan, R. (2017). Role of Teacher in Teaching English to Non Native Speakers of Indian Origin. (ICIATE, Ed.) International Jourmal of Engineering Research and technology , 5 (1).

9. Singh, H. (2003). Building Effective Blended Learning Programme. Educational Technology , 43 (6), 51-54.

10. Thorne, K. (2003). Blended Learning: How to integrate online \& traditional learning. London: Ans Sterling: Koran Page.

11. Valiathan, P. (2002). Blended Learning Models. Retrieved November 2019, from https://purnima-valiathan.com/wp-content/uploads/2015/09/Blended-LearningModels-2002-ASTD.pdf 